\title{
BOWEL PREPARATION FOR COLONOSCOPY: COMPARISON OF MANNITOL AND SODIUM PHOSPHATE. RESULTS OF A PROSPECTIVE RANDOMIZED STUDY
}

\author{
Angelita Habr-Gama, Robert William de Azevedo Bringel, Sergio Carlos Nahas, \\ Sergio Eduardo de Alonso Araújo, Afonso Henrique de Souza Junior, João Elias \\ Calache and Paulo Arruda Alves
}

HABR-GAMA A et al. - Bowel preparation for colonoscopy: comparison of mannitol and sodium phosphate. Results of a prospective randomized study. Rev. Hosp. Clín. Fac. Med. S. Paulo 54 (6):187-192, 1999.

SUMMARY: Method: Eighty patients were prospectively randomized for precolonoscopic cleansing either with $750 \mathrm{ml}$ of $10 \%$ mannitol (Group M) or $180 \mathrm{ml}$ of a sodium phosphate preparation (Group NaP). Laboratory examinations before and after preparation on all patients included hemoglobin, hematocrit, sodium, potassium, phosphorous, calcium and serum osmolarity. A questionnaire was used to assess undesirable side effects and patient tolerance to the solution. The quality of preparation was assessed by the endoscopist who was unaware of the solution employed.

Results: Statistically significant changes were verified in serum sodium, phosphorous, potassium and calcium between the two groups, but no clinical symptoms were observed. There were no significant differences in the frequency of side effects studied. Six of the eight patients in Group NaP who had taken mannitol for a previous colonoscopy claimed better acceptance of the sodium phosphate solution. The endoscopic-blinded trial reported excellent or good bowel preparation in $85 \%$ prepared with sodium phosphate versus $82.5 \%$ for mannitol ( $\mathrm{p}=0.37$ ).

Conclusions: Quality of preparation and frequency of side effects was similar in the two solutions. The smaller volume of sodium phosphate necessary for preparation seems to be related to its favorable acceptance. Nevertheless, the retention of sodium and phosphate ions contraindicates the use of sodium phosphate in patients with renal failure, cirrhosis, ascites, and heart failure.

DESCRIPTORS: Bowel preparation. Colonoscopy. Oral solution of sodium phosphate.

The ideal method of bowel preparation for colonoscopy associates effectiveness, safety, ease of administration, low cost, and good patient acceptance. Mannitol (M) and polyethyleneglycol (PEG) are the most commonly utilized, with various articles confirming that both are equally effective and safe for bowel cleansing ${ }^{1,6}$. Nevertheless, about $5-15 \%$ of patients experience difficulty in swallowing the necessary volume, especially when using PEG, resulting in inadequate bowel preparation ${ }^{7,8}$. Use of sodium phosphate is an attempt to improve tolerance, since a considerably smaller volume is required, maintaining the same effectiveness ${ }^{9,15}$. We confirmed these findings for sodium phos- phate compared to PEG in a randomized prospective study on 90 patients undergoing elective colorectal surgery ${ }^{16}$ encouraging us to also utilize sodium phosphate for precolonoscopic cleansing.

The purpose of the present randomized, prospective study is to compare precolonscopic preparation with mannitol and sodium phosphate, analyzing for their effectiveness, safety, and side effects.

From the Division of Coloproctology, University of São Paulo School of Medicine, São Paulo - Brazil.

\section{PATIENTS AND METHOD}

The study was prospective and included 80 patients undergoing elective colonoscopy in the Colonoscopy Unit of the Coloproctology Division of Hospital das Clinicas, University of São Paulo during the period from April to July 1998. Only patients with a diagnosis of renal failure, liver disease with ascites, and severe congestive heart failure, and those undergoing emergency colonoscopies were excluded from this investigation. After an explanation about the study, all patients signed a consent agreement.

The patients were randomized by simple heads-or-tails allotment and 
were given $10 \%$ mannitol (Group M) or sodium phosphate (Group $\mathrm{NaP}$ ) for bowel preparation. Both solutions are currently produced at our pharmacy. Patients were instructed to follow a liquid diet without residues, starting after lunch on the day prior to the examination. Subjects in Group M were also instructed to take four tablets of bisacodyl (Dulcolax ${ }^{\circledR}$, Boehringer De Angeli, São Paulo, SP) on the night prior to the exam. They were admitted on the morning of the colonoscopy and received two $\mathrm{ml}$ of metoclopramide intramuscularly prior to drinking $750 \mathrm{ml}$ of $10 \%$ mannitol $^{21}$. The sodium phosphate solution (monobasic sodium phosphate: $0.24 \mathrm{~g} / \mathrm{ml}$ and dibasic sodium phosphate: $0.09 \mathrm{~g} / \mathrm{ml}$ ) was administered in two equal doses of $90 \mathrm{ml}$. The first dose on the afternoon prior to the examination (16:00h) and the second on the morning of the colonoscopy (07:00h), for a total of $180 \mathrm{ml}$. The colonoscopies were performed in the late morning.

The following data were recorded: sex, age, and variation of body weight (patients were weighed immediately before bowel prep and right after examination). Laboratory tests (hemoglobin level and hematocrit, serum $\mathrm{Na}$, serum $\mathrm{K}$, serum $\mathrm{P}$, serum $\mathrm{Ca}$, and serum osmolarity) were performed in all, immediately before and after bowel cleansing. Upon completion of bowel preparation and before colonoscopy, patients filled out a questionnaire with the objective of identifying side effects (nausea, vomiting, abdominal pain, abdominal distension, dizziness, perianal irritation) and degree of acceptance of the solution given.

Bowel preparation was evaluated by the endoscopist in a blinded-trial and graded as:

- Excellent - presence of clear fluid, without any fecal material

- Good - presence of cloudy fluid, but without residues.

- Poor - presence of residues.
The endoscopic diagnosis and complications were also recorded. Statistical analysis was based on Fisher and chi-square tests, with values of $p<0.05$ considered statistically significant.

Forty of the 80 patients in the study received $10 \%$ mannitol for bowel preparation and the other 40 received sodium phosphate. Table 1 displays the data of the two groups. No statistically signifi-
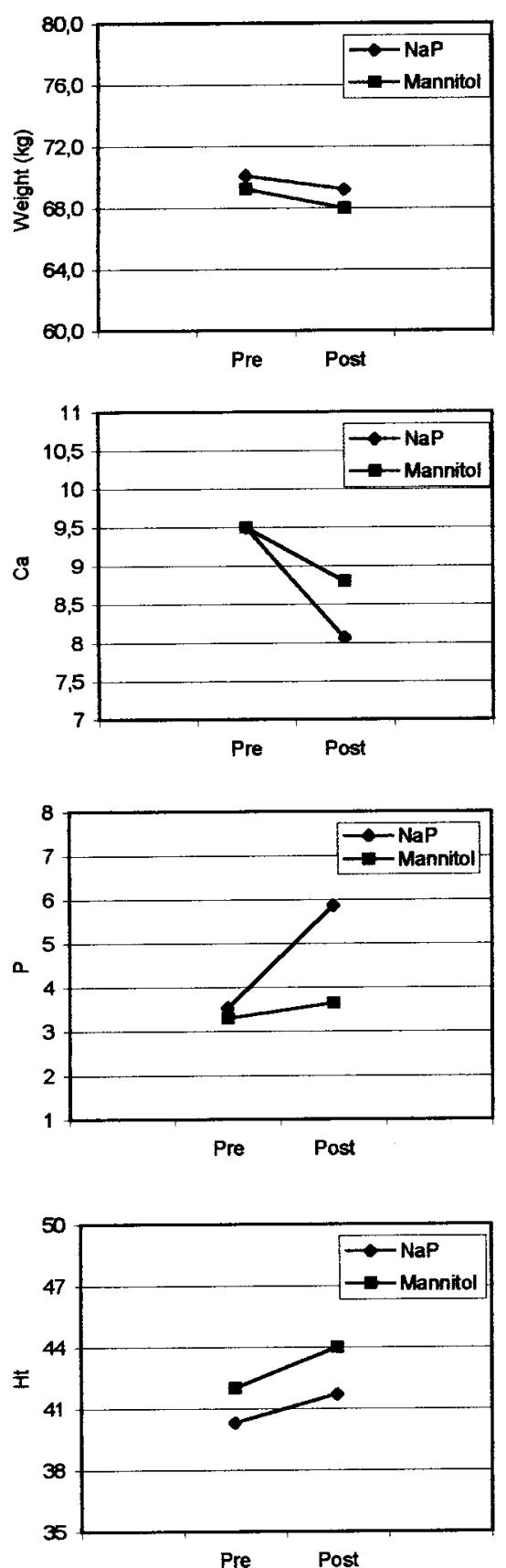

Figure 1 - Graphs, illustrating weight and laboratory examinations.
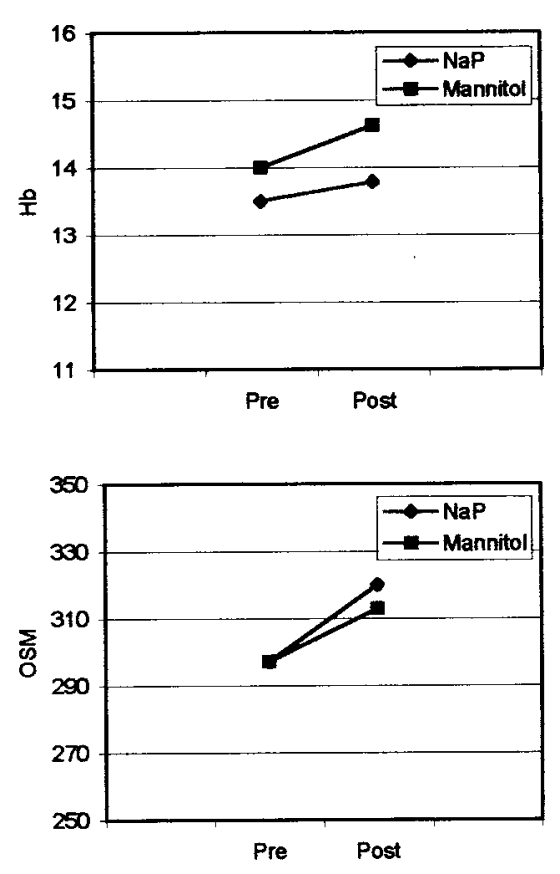

cant difference was noted regarding gender or age between the groups.

\section{RESULTS}

The biochemical analysis demonstrated a significant rise in serum sodium and phosphorous and a marked drop in potassium and calcium in
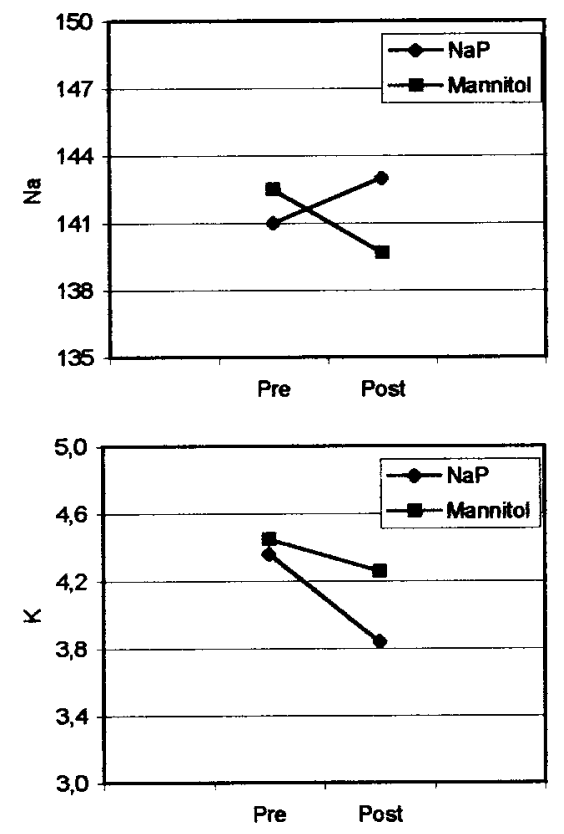
Group NaP compared to Group M (p $=0.0001)$. Nevertheless, there were no clinical symptoms. A slight increase occurred in hemoglobin $(\mathrm{p}=0.16)$, hematocrit $(\mathrm{p}=0.36)$, and serum osmolarity $(p=0.74)$ in both groups, but these were without statistical significance. Weight loss $(\mathrm{kg})$ in both groups was similar, $0.80 \pm 1.4$ for the Group NaP and $1.1 \pm 1.2$ for the Group M, without a statistically significant difference between them $(\mathrm{p}=0.42)$. Figure 1 illustrates weight variations and laboratory parameters between the two groups.

Bowel preparation was judged excellent or good in $85 \%$ of cases prepared with sodium phosphate and in $82.5 \%$ prepared with mannitol $(\mathrm{p}=0.37)$. A poor preparation was obtained in $15 \%$ and $17.5 \%$ in Group $\mathrm{NaP}$ and Group $\mathrm{M}$ respectively. In three patients who had been prepared with mannitol, it was impossible to complete the colonoscopy because of poor bowel cleansing. Table 2 displays patient distribution based on quality of bowel preparation and solution utilized.

Nausea and vomiting were the most frequent undesirable effects reported by patients of both groups. They occurred in $50 \%$ and $18 \%$ of those taking sodium phosphate and in $30 \%$ and $18 \%$ in those taking mannitol, respectively. Eight patients receiving sodium phosphate had been prepared for a previous colonoscopy with mannitol, and six of them claimed better acceptance of sodium phosphate. The Fisher test did not demonstrate a significant difference between the two groups for these variables (nausea, $\mathrm{p}=0.11$; vomiting, $\mathrm{p}=1.00$ ).

Distribution of endoscopic findings according to the type of the solution is displayed in Table 3. There was no statistically significant difference between the two groups $(\mathrm{p}>0.01)$.

\section{DISCUSSION}

The success of colonoscopy is di-

Table 1 - Gender and age distribution in the two groups.

\begin{tabular}{|c|c|c|c|c|}
\hline & Total & Mannitol & $\mathrm{NaP}$ & $\mathrm{p}$ \\
\hline $\mathrm{N}(\%)$ & $80(100 \%)$ & & $40(50 \%)$ & $40(50 \%)$ \\
\hline Males & $43(54 \%)$ & & $22(55 \%)$ & $21(52 \%)$ \\
\hline $\begin{array}{l}1.00 \\
\text { Mean age }\end{array}$ & $56.0 \pm 16.3$ & & $56.0 \pm 14.9$ & $56.1 \pm 12.9$ \\
\hline
\end{tabular}

Table 2 - Quality of bowel preparation and group studied.

\begin{tabular}{lrlll}
\hline Quality of preparation & \multicolumn{1}{l}{$\mathrm{NaP}$} & \multicolumn{2}{c}{$\mathrm{M}$} & \multicolumn{1}{c}{ Total } \\
\hline Excellent & $23(57.5 \%)$ & $26(65 . \%)$ & $49(61.2 \%)$ \\
Good & $11(27.5 \%)$ & 7 & $(17.5 \%)$ & $18(22.5 \%)$ \\
Poor & $6(15 \%)$ & $7(17.5 \%)$ & $13(16.3 \%)$ \\
Total & $40(100 \%)$ & $40(100 \%)$ & $80(100 \%)$ \\
\hline
\end{tabular}

Table 3 - Distribution of endoscopic findings in the two groups.

\begin{tabular}{lrrrr}
\hline Diagnosis & \multicolumn{2}{c}{ NaP } & \multicolumn{2}{c}{$\mathrm{M}$} \\
\hline Normal & 20 & $(50 \%)$ & 18 & $(46 \%)$ \\
Polyp & 6 & $(15 \%)$ & 6 & $(15 \%)$ \\
Colorectal neoplasm & 3 & $(7.5 \%)$ & 5 & $(12 \%)$ \\
UC & $5(12.5 \%)$ & 3 & $(7.5 \%)$ \\
Diverticular disease & 4 & $(10 \%)$ & 2 & $(5 \%)$ \\
Crohn's disease & 0 & $(0 \%)$ & 1 & $(2.5 \%)$ \\
Vascular ectasia & 0 & $(0 \%)$ & 1 & $(2.5 \%)$ \\
Others & 2 & $(5 \%)$ & 4 & $(10 . \%)$ \\
\hline Total & $40(100 \%)$ & $40(100 \%)$ \\
\hline
\end{tabular}

rectly related to the degree of bowel cleansing since it is based on perfect visualization of the colorectal mucosa. Thus, with improper cleansing, small lesions can be obscured by fecal residues in the lumen, impairing detection and treatment of various colonic diseases.

The ideal method for precolonoscopy preparation should be effective, safe, easily administered, and well tolerated by the patient. Anterograde methods fulfill these requirements and have gradually replaced the conventional method, based on diet, laxatives, and enemas. Mannitol and polyethyleneglycol (PEG) are currently the most commonly utilized oral solutions, each with inherent advantages and disadvantages ${ }^{1-6}$. Both solutions accomplish adequate colonic cleansing when properly administered.
The monosaccharide mannitol solution is almost non-absorbable in concentrations ranging from 5-20\% and volumes of 500 to $750 \mathrm{ml}$. Its effect is due to the promotion of osmotic diarrhea with practically no absorption of water. Various studies have confirmed the effectiveness and safety of this solution for colonoscopic preparation and have achieved excellent or good results in over $90 \%$ of cases ${ }^{1,2}$. Because of the risk of explosion during electrocauterization resulting from fermentation of mannitol by hydrogen- and methaneproducing intestinal bacteria, its use has been criticized and restricted in various centers in the United States and Europe $^{17-19}$.

PEG preparations eliminate risk of explosion and are osmotically neutral, thus reducing the possibility of promot- 
ing significant changes in fluids or electrolytes. For a proper cleansing, of a greater volume of PEG than mannitol must be ingested (about four liters). Drinking large volumes of liquids results in unacceptable bowel preparation in about $5-15 \%$ of patients, especially those with pharyngeal reflex problems, such as the elderly or those who have had strokes or neurological disturbances $^{7-8}$, and children ${ }^{14}$.

The present study was motivated by the good results obtained with the sodium phosphate solution for mechanical bowel preparation for elective colorectal surgery presented in the literature $^{21}$ and by our own experience ${ }^{16}$ confirming better acceptance of sodium phosphate, especially because of the small volume utilized for colonoscopic bowel preparation. Some researchers have also demonstrated the advantages of sodium phosphate solution, especially comparing its use with the PEG solution ${ }^{9-15}$.

In the present study, we compared the use of sodium phosphate and $10 \%$ mannitol, since the latter has been our method of choice for bowel preparation for colonoscopy for many years. We were not able to find a report of a similar investigation comparing sodium phosphate and mannitol, probably because of the preference for PEG in the majority of American and European medical centers.

The number of side effects was similar in the two groups, especially regarding nausea and vomiting. Despite more frequent bouts of nausea $(50 \%$ vs. $30 \%)$ in the sodium phosphate group, the incidence of vomiting was identical in both groups (18\%). Probably, the routine use of metoclopramide in patients receiving mannitol contributed to their lower incidence of nausea. In the literature, the incidence of nausea and vomiting resulting from sodium phosphate ranges from 11.2 to $44.3 \%$ and 5.4 to $8.6 \%$, respectively $y^{11,10,15}$. Frommer ${ }^{15}$ compared sodium phosphate and PEG in 486 patients submitted to colonoscopy and found a greater incidence of minor side effects, such as, nausea and vomiting in patients prepared with sodium phosphate. However, the majority of articles comparing the two solutions (PEG $\mathrm{x}$ $\mathrm{NaP}$ ) mention a lower incidence of side effects with sodium phosphate ${ }^{9-14,16}$.

The acceptance of ingesting one solution versus the other is difficult to compare, since acceptance is a subjective variable, perhaps reliably reported only by patients who have taken both solutions. In the present study, eight patients in the sodium phosphate group had been prepared with mannitol for previous examination, and six of them indicated better acceptance of sodium phosphate. The other two did not perceive a difference. Vanner et al. ${ }^{9}$ deemed sodium phosphate more easily acceptable than PEG in a prospective study including 102 patients, and 37 of them who had been previously prepared with PEG stated their preference for sodium phosphate. Other reports have demonstrated that there is no significant clinical difference in the incidence and intensity of side effects, but that swallowing a smaller volume of sodium phosphate solution compared to PEG is more easily accepted ${ }^{10-14}$.

Hyperphosphatemia and hypocalcemia were the most common laboratory changes found in the sodium phosphate group, but there were no detectable clinical symptoms. Various articles have mentioned temporary hyperphosphatemia after the use of sodium phosphate ${ }^{9-12,15}$. Although there are no reports of clinical problems due to increased serum levels of phosphate in normal adults, sodium phosphate should be avoided in patients with renal diseases ${ }^{9,11,16}$. There was also greater retention of sodium ions, and greater loss of potassium in patients taking sodium phosphate, but without associated clinical symptoms in any of the cases. Nevertheless, this data obliges us to issue a warning restricting the use of sodium phosphate in patients with congestive heart failure or cirrhosis with ascitis.

Concerning the quality of bowel preparation, both solutions obtained similar results, with excellent or good in $85 \%$ and $82.5 \%$ respectively for sodium phosphate and mannitol. Our data is similar to those obtained in other investigations studying the effectiveness of sodium phosphate for colonoscopy ${ }^{9-15}$. Some researchers consider sodium phosphate more effective than PEG for bowel cleansing, justifying these results on the basis of the greater acceptance of sodium phosphate, which requires a markedly smaller volume than $\mathrm{PEG}^{9,11,13,14}$. The examination was discontinued in three patients taking mannitol due to inadequate cleansing, because of vomiting in two of them.

The use of sodium phosphate has been associated with coarse macroscopic changes in the bowel mucosa ${ }^{20}$. These changes range from friability and hyperemia to aphthoid injuries. However, we did not note these changes in any patient in the present study.

Based on the results of this series, we conclude that bowel preparation for elective colonoscopy may be equally effective and safe with either mannitol $10 \%$ or sodium phosphate solutions. However, due to the smaller volume necessary for adequate bowel cleansing, sodium phosphate seems to be better tolerated than mannitol. This is especially important in patients with difficulty in swallowing large volumes. Perhaps routine administration of an oral or parenteral antiemetic can further improve acceptance of sodium phosphate. However, retention of phosphate and sodium ions in patients with renal problems, liver diseases with ascites, and those with congestive heart failure makes the use of sodium phosphate solution inadvisable in patients with these complications. 
HABR-GAMA A e col. - Preparo intestinal para colonoscopia: manitol vs fosfato de sódio. Resultados de estudo prospectivo e randomizado. Rev Hosp Clín Fac Med S Paulo 54 (6):187-192, 1999.

Métodos: Oitenta pacientes foram prospectivamente randomizados para receber $750 \mathrm{ml}$ de manitol a $10 \%(\mathrm{M})$ ou $180 \mathrm{ml}$ de solução à base de fosfato de sódio (FS), como preparo intestinal para colonoscopia eletiva. Todos os pacientes foram submetidos a avaliação laboratorial (hemoglobina, hematócrito, sódio, potássio, fósforo, cálcio e osmolaridade sérica) antes e depois do preparo. Completado o preparo intestinal, antes da realização do exame, os pacientes foram avaliados por questi- onário com a finalidade de identificar efeitos indesejáveis e tolerabilidade inerentes à solução empregada. A qualidade do preparo foi avaliada pelo colonoscopista, que desconhecia o tipo de solução empregada.

Resultados: A análise bioquímica demonstrou elevação significativa dos níveis séricos de sódio e fósforo no grupo do FS, bem como uma queda mais acentuada do pótassio e cálcio séricos neste grupo, mas nenhuma destas alterações foi clinicamente sintomática. Não houve diferença significante na incidência de seis efeitos colaterais pesquisados. Seis de oito pacientes do grupo FS que em exame colonóscopico anterior haviam recebido manitol, manifestaram melhor tolerabilidade com a solução de FS. A qualidade do preparo foi considerada excelente ou boa em $85 \%$ dos casos preparados com FS e em $82,5 \%$ do grupo $\mathrm{M}(\mathrm{p}=0.37)$.

Conclusão: As duas soluções foram similares quanto à qualidade do preparo e incidência de efeitos colaterais. $\mathrm{O}$ menor volume necessário para o preparo com FS parece estar relacionado com uma melhor tolerabilidade desta solução. No entanto, a retenção dos íons sódio e fosfato com o uso da solução de FS torna desaconselhável seu emprego em pacientes com insuficiência renal, cirrose e insuficiência cardíaca.

DESCRITORES: Preparo intestinal. Colonoscopia. Solução oral de fosfato de sódio.

\section{REFERENCES}

1. BRUNETTI Neto C, HABR-GAMA A, MORAES RS et al. - Limpeza mecânica do cólon. Experiência em 100 casos de colonoscopia. Rev Bras Coloproct 1980; 4:6-23.

2. HABR-GAMA A, TEIXEIRA MG, ALVES PR et al. - Emprego da solução de manitol a $10 \%$ no preparo do intestino grosso para colonoscopia e cirurgia. Rev Hosp Clín Fac Med S Paulo 1981; 36:239-243.

3. NAHAS SC, OLIVEIRA FILHO DES, ARAÚJO SE et al. Colonoscopia: indicações, contra-indicações e complicações. Rev Hosp Clin Fac Med S Paulo 1998; 53(2):91-99.

4. DAVIS GE, SANTA ANA CA, MORAWSKI SG et al. - Development of a lavage solution associated with minimal water and electrolyte absorption or secretion. Gastroenterology 1980; 78:991-995.

4. GOLDMAN J \& REICHELDERFER M - Evaluation of rapid colonoscopy preparation using a new gut lavage solution. Gastrointest Endosc 1982; 28:9-11.

6. DIPALMA JA, BRADY CE, STEWART DL et al. - Comparison of colon cleansing methods in preparation for colonoscopy. Gastroenterology 1984; 86:856-860.

7. DIPALMA JA \& MARSHAL JB - Comparison of a new sulfate-free polyethylene glycol electrolyte lavage solution versus a standard solution for colonoscopy cleansing. Gastrointest Endosc 1990; 36:285-289
8. DIPALMA JA, BRADY CE \& PIERSON WP - Colon cleansing: acceptance by older patients. Am J Gastroenterol 1986; 81:652-655.

9. VANNER SJ, MACDONALD PH, PATERSON WG et al. - A randomized prospective trial comparing oral sodium phosphate with standard polyethylene glycol-based lavage solution (Golytely) in the preparation of patients for colonoscopy. Am J Gastroenterol 1990; 85(4):422-427.

10. MARSHAL JB, PINEDA JJ, BARTHEL JS et al. - Prospective, randomized trial comparing sodium phosphate solution with polyethylene glycol-electrolyte lavage for colonoscopy preparation. Gastrointest Endosc 1993; 39:631-634.

11. COHEN SM, WEXNER SD, BINDEROW SR et al. - Prospective, randomized, endoscopic-blinded trial comparing precolonoscopy bowel cleansing methods. Dis Colon Rectu 1994; 37:689-696.

12. HENDERSON JM, BARNETT L, URGEON DK et al. - Crause I, Nostrant TT. Single-day, divided-dose oral sodium phosphate laxative versus intestinal lavage as preparation for colonoscopy: efficacy and patient tolerance. Gastrointest Endosc 1995; 42(3):238-243.

13. CHIA YW, CHENG LC, GOH PM et al. - Role of oral sodium phosphate and its effectiveness in large bowel preparation for outpatient colonoscopy. J R Coll Surg Edinb 1995; 40(6):374-376. 
14. GREMSE DA, SACKS AI \& RAINES S - Comparison of oral sodium phosphate to polyethylene glycol-based solution for bowel preparation for colonoscopy in children. J Pediatr Gastroenterol Nutr 1996; 23(5):586-590.

15. FROMMER D - Cleansing ability and tolerance of three bowel preparations for colonoscopy. Dis Colon Rectum 1997; 40(1):100-104.

16. HABR-GAMA A, KISS DR, ARAUJO, SE et al. - Preparo intestinal para cirurgia colorretal eletiva: politilenoglicol (PEG) X fosfato de sódio (FS) - resultados de estudo prospectivo e randomizado. Rev Bras Coloproct 1998; 18(2):85-89.

17. BIGARD MA, GAUCHER P \& LASSAILE C - Fatal colonic explosion during colonoscopic polypectomy. Gastroenterology 1979; 77:1307-1310.

18. KEIGHLY MR, TAYLOR EW, HARES MM et al. - Influence of oral mannitol bowel preparation on colonic microflora and the risk of explosion during endoscopic diathermy. Br J Surg 19816;8:554-556.
19. AVGERINOS A, KALAANTZIS N, REKOUIMS G, et al. Bowel preparation and the risk of explosion during colonoscopic polypectomy. Gut 1984; 25:361-364.

20. OLIVEIRA L, WEXNER SD, DANIEL N et al. - Mechanical bowel preparation for elective colorectal surgery. A prospective, randomized, surgeon-blinded trial comparing sodium phosphate and polyethylene glycol-based oral lavage solutions. Dis Colon Rectum 1997; 40 (5):585-591.

21. ALVES PR, SOUZA Jr AH, HABR-GAMA A et al. - Express mannitol: a safe and fast bowel preparation for colonoscopy used on 2,400 consecutive patients. ABCD Arq Bras Cir Dig 1991; 6: $20-23$.

Received for publication on the 26/04/99 